\begin{tabular}{|l|l|l||}
\hline \multicolumn{2}{|c|}{ PublisherInfo } \\
\hline \hline PublisherName & $:$ & BioMed Central \\
\hline \hline PublisherLocation & $:$ & London \\
\hline \hline PublisherImprintName & $:$ & BioMed Central \\
\hline \hline
\end{tabular}

\title{
Three-spined sticklebacks
}

\begin{tabular}{|l|l|l||}
\hline \multicolumn{2}{|c|}{ ArticleInfo } \\
\hline \hline ArticleID & $:$ & 4283 \\
\hline \hline ArticleDOI & $:$ & $10.1186 /$ gb-spotlight-20011221-01 \\
\hline \hline ArticleCitationID & $:$ & spotlight-20011221-01 \\
\hline \hline ArticleSequenceNumber & $:$ & 354 \\
\hline \hline ArticleCategory & $:$ & Research news \\
\hline ArticleFirstPage & $:$ & 1 \\
\hline \hline ArticleLastPage & $:$ & 2 \\
\hline \hline & & RegistrationDate : 2001-12-21 \\
ArticleHistory & $:$ & OnlineDate $\quad$ 2001-12-21 \\
\hline \hline ArticleCopyright & $:$ & BioMed Central Ltd2001 \\
\hline \hline ArticleGrants & $:$ & \\
\hline \hline ArticleContext & $:$ & 130592211 \\
\hline \hline
\end{tabular}


The three-spined stickleback (Gasterosteus aculeatus) is a teleost fish that has undergone rapid adaptive evolution and speciation within the last 15,000 years. The benthic species has greatly reduced body armour, increased body depth and fewer gill rakers than the limnetic species, which more closely resemble an ancestral marine fish. In the December 20/27 Nature, Peichel et al. report the generation of a genome-wide linkage map for G. aculeatus (Nature 2001, 414:901-905). They collected 1,176 clones containing microsatellite CA-dinucleotide repeat sequences, and used these to analyse a genetic cross between benthic and limnetic species (from Priest Lake, British Columbia), to create a linkage map with an average density of one marker per four centiMorgans. This map will be useful for identifying genetic loci associated with morphological traits. Peichel et al.found that the number of short gill rakers and the amount of skeletal armour, and variations in spine length, could be linked to specific genomic regions.

\section{References}

1. The three-spined stickleback, [http://www.waterland.net/visschenwinkel/threestickle.htm]

2. Nature, [http://www.nature.com] 